This article was published in International Biodeterioration \& Biodegradation http://dx.doi.org/10.1016/j.ibiod.2013.03.024

\title{
Use of phenyl isothiocyanate for biofilm prevention and control
}

\author{
Ana Cristina Abreu ${ }^{a}$, Anabela Borges ${ }^{a, b}$, Filipe Mergulhão ${ }^{a}$, Manuel Simões ${ }^{a, *}$ \\ a LEPAE, Department of Chemical Engineering, Faculty of Engineering, University \\ of Porto, Rua Dr. Roberto Frias, s/n, 4200-465 Porto, Portugal \\ b CECAV e Veterinary and Animal Science Research Center, Quality and Food \\ Safety of Animal Products Group, University of Trás-os-Montes and Alto Douro, \\ Apartado 1013, 5000-801 Vila Real, Portugal
}

\begin{abstract}
The purpose of the present study was to assess the antibacterial activity of phenyl isothiocyanate (PITC), a synthetic isothiocyanate, on biofilms of Escherichia coli and Staphylococcus aureus. The effects of PITC on bacterial free energy of adhesion and motility were also investigated. Biofilm formation in 96-well polystyrene microtiter plates was quantified by crystal violet staining and the metabolic activity of those biofilms was assessed with alamar blue. The viability and culturability of the biofilm bacteria after exposure to PITC were determined. The highest removal and metabolic activity reduction of biofilms with PITC was around $90 \%$ for both bacteria. Treatment with PITC enabled 4.5 and $4.0 \log _{10}$ reductions of the number of viable cells for $E$. coli and S. aureus, respectively; and no colony forming units (CFUs) were detected. PITC also affected the adhesion process and motility of bacteria, greatly preventing biofilm formation. In conclusion, PITC enabled both biofilm prevention and control, promoting high biofilm removal and inactivation activities, suggesting that this compound is a promising disinfectant.
\end{abstract}

\section{Introduction}

In the last decades, an increasing incidence of food poisoning cases has been reported due to the contamination of food with pathogens and spoilage organisms. This has prompted the need for hygiene and sanitary actions and regulatory practices regarding food control, food safety and food trade processes (Kühn et al., 2003). The emphasis on safer foods and longer shelf-life has led to higher frequency of disinfection of food-contact surfaces, equipment, utensils, etc. (Langsrud et al., 2003). The recurrent application of disinfectants at sub-optimal conditions (e.g. concentration, temperature and exposure time) has resulted in the increased resistance of microorganisms (Zottola and Sasahara, 1994). Resistant microorganisms have been responsible for a decreased efficiency of disinfection programs and, consequently, for severe contaminations in industrial, environmental and biomedical set- tings (Talon, 1999; Chorianopoulos et al., 2011). The ability of bacteria to adhere to surfaces is one of the most important causes for the failure of disinfection programs (Gilbert et al., 2002a, 2002b). Bacterial adhesion is implicated in the contamination of medical devices, industrial cooling water systems and food processing 
equipment (Glinel et al., 2008). These attached microorganisms can form biofilms, where they enjoy a number of advantages over their planktonic cells, particularly an increased tolerance to antimicrobials (Busetti et al., 2010; Simões et al., 2010a). Bacteria in biofilms can be 10 to up 1000 times more resistant to the effects of antimicrobial agents than their planktonic counterparts (Amorena et al., 1999; Mah and O'Toole, 2001; Smith, 2005; Zahin et al., 2010). Biofilm resistance is not completely understood and the persistence of biofilms, even after aggressive antimicrobial treatment, continues to motivate the search for new control strategies (Xu et al., 2000; Inoue et al., 2008).

New disinfection compounds and processes are necessary in order to ensure high levels of sanitation (Grönholm et al., 1999; Wutzler et al., 2005). Substantial resources have been invested in the research of new antimicrobial compounds (Cowan, 1999; Simões et al., 2008; Zahin et al., 2010). These compounds must be efficient in the inactivation of pathogens while maintaining the organoleptic properties of the product (Bermúdez-Aguirre and Barbosa-Cánovas, 2012). Plants are an interesting source of such compounds as they produce an enormous array of phytochemicals with antimicrobial activity, most of them related to defense/stress mechanisms against microorganisms, insects, nematodes and even other plants (Dangl and Jones, 2001; Dixon, 2001). Glucosinolates are sulphur-containing glucosides found in several plants, including the Cruciferae family (which comprises well-known plants such as broccoli, cabbage, cauliflower, watercress), and are hydrolyzed as a defense mechanism of the plant, releasing several compounds with antimicrobial activity (glucosinolate hydrolysis products e GHP) (Gomes de Saravia and Gaylarde, 1998; Fahey et al., 2001). Amongst these products, isothiocyanates (ITCs) are the most potent inhibitors of microbial activity (Saavedra et al., 2010). ITCs have an electrophilic character, due to the presence of a $-\mathrm{N}=\mathrm{C}=\mathrm{S}$ group, which is responsible for their strong reaction with amines and cellular thiols. Thus, ITCs are capable to interaction with diverse biomolecules (Saavedra et al., 2010).

In the present study, a synthetic ITC e phenyl isothiocyanate (PITC) (Fig. 1) was tested in the prevention and control of biofilms formed by $\mathrm{E}$. coli and $\mathrm{S}$. aureus in 96 -well polystyrene microtiter plates. S. aureus is an important foodborne pathogen and a major cause of staphylococcal food poisoning cases (Chorianopoulos et al., 2011). The presence of E. coli in foods such as meat, fish and milk is an indicator of fecal contamination, causing outbreaks of diarrhea, gastroenteritis and hemolytic uremic syndrome (Mauriello et al., 2005). E. coli has also shown the ability to attach strongly to leafy structures (Bermúdez-Aguirre and Barbosa-Cánovas, 2012). To our knowledge, there are no studies on the activity of PITC against biofilms. Since biofilm formation is a multistep process, starting with transient adhesion to a surface, the effects of the PITC were also evaluated on bacterial adhesion and motility. Different approaches were tested in order to characterize the activity of PITC in the prevention of biofilm formation and in the removal and inactivation of $24 \mathrm{~h}$ aged biofilms. Also, the effects of PITC were tested in pre-stressed biofilms, whose cells were previously exposed to the chemical.

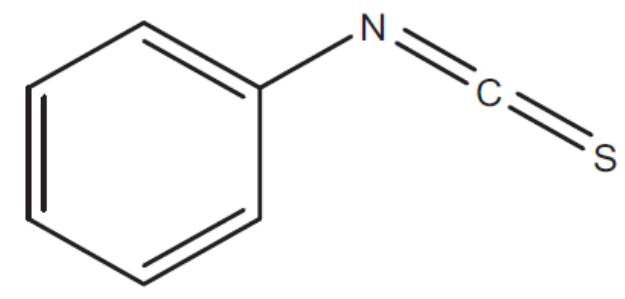

Fig. 1. Chemical structure of PITC. 


\section{Materials and methods}

\subsection{Bacteria}

E. coli CECT 434 and S. aureus CECT 976 were used in this study. These bacteria were already used as model microorganisms for antimicrobial tests with phytochemical products (Simões et al., 2008; Saavedra et al., 2010; Borges et al., 2013). Bacteria were picked from overnight cultures in $250 \mathrm{~mL}$ flasks with $100 \mathrm{~mL}$ of Mueller-Hinton broth (MHB, Merck, Germany) incubated at $30^{\circ} \mathrm{C}$ and under $150 \mathrm{rpm}$ of agitation (CERTOMAT® BS-1, Sartorius AG, Germany).

\subsection{Minimum inhibitory concentration}

PITC (Sigma, Portugal) was prepared in dimethyl sulfoxide (DMSO; Sigma). To determine whether the presence of PITC had effects on bacterial growth in liquid culture, the minimal inhibitory concentration (MIC) was determined using the standard broth microdilution method (CLSI, 2007). MIC was defined as the lowest concentration of the antimicrobial product that inhibited bacterial growth. Three independent experiments were performed for each bacterium and condition.

\subsection{Free energy of adhesion}

The free energy of adhesion between the bacterial cells and polystyrene (PS) surfaces was assessed according to the procedure described by Simões et al. (2010a) and calculated through the surface tension components of the entities involved in the adhesion process by the thermodynamic theory expressed by the Dupre equation. When studying the interaction between one bacteria (b) and a substratum (s) that are immersed or dissolved in water (w), the total interaction energy, $\Delta G_{b w s}^{T O T}$, can be expressed by the interfacial tensions components as follows:

$\Delta G_{b w s}^{T O T}=\gamma_{b s}-\gamma_{b w}-\gamma_{s w}$

For instance, the interfacial tension for one system of interaction (bacteria/substratum - $\gamma_{b s}$ ) can be defined by the thermodynamic theory according to the following equations:

$\gamma_{b s}=\gamma_{b s}^{L W}+\gamma_{b s}^{A B}$

$\gamma_{b S}^{L W}=\gamma_{b}^{L W}+\gamma_{s}^{L W}-2 \times \sqrt{\gamma_{b}^{L W} \times \gamma_{s}^{L W}}$

$\gamma_{b s}^{A B}=2 \times\left(\sqrt{\gamma_{b}^{+} \times \gamma_{b}^{-}}+\sqrt{\gamma_{s}^{+} \times \gamma_{s}^{-}}-\sqrt{\gamma_{b}^{+} \times \gamma_{s}^{-}}-\sqrt{\gamma_{b}^{-} \times \gamma_{s}^{+}}\right.$

The other interfacial tension components, $\gamma_{b w}$ (bacteria/water) and $\gamma_{s w}$ (substratum/water), were calculated in the same way, which allowed the assessment of thermodynamic energy of adhesion. Thermodynamically, if $\Delta G_{b w s}^{T O T}<0 \mathrm{~mJ} \mathrm{~m}^{-2}$, the bacterial adhesion to the substratum is favorable. If $\Delta G_{b w s}^{T O T}>0 \mathrm{~mJ} \mathrm{~m}^{-2}$, adhesion is not expected to occur (Simões et al., 2010a). The hydrophobicity of PS was obtained from Simões et al. (2010a): $\Delta G_{b w s}^{T O T}=-44 \mathrm{~mJ} \mathrm{~m}^{-2}$. 


\subsection{Motility}

Overnight cultures grown on Luria-Bertani broth (LBB; Merck, Germany) were used to characterize bacterial motility. A volume of $15 \mu \mathrm{L}$ of these cultures were applied in the center of plates con- taining $1 \%$ tryptone, $0.25 \% \mathrm{NaCl}$, and $0.3 \%$ or $0.7 \%(\mathrm{w} / \mathrm{v})$ agar (Merck, Germany) for swimming/sliding and swarming motilities, respectively (Butler et al., 2010; Stickland et al., 2010). PITC at MIC and 5 MIC were incorporated in the growth medium (tempered at $45^{\circ} \mathrm{C}$ ). Plates were incubated at $30^{\circ} \mathrm{C}$ and the diameter $(\mathrm{mm})$ of the bacterial motility halos were measured at 24,48 and $72 \mathrm{~h}$. Three plates were used to evaluate the motility of each bacterium. The control was performed with DMSO.

\subsection{Biofilm formation in sterile 96-well polystyrene microtiter plates}

Biofilms were developed according to the modified microtiter plate test proposed by Stepanovic et al. (2000). For each bacterium, at least 16 wells of a sterile 96-well PS microtiter plate (Orange Scientific, USA) were filled with $200 \mu \mathrm{L}$ of overnight batch cultures in MHB (with a density of $1 \times 108$ cells $\mathrm{mL}^{-1}$ ) and incubated overnight at $30^{\circ} \mathrm{C}$ and $150 \mathrm{rpm}$. The PS microtiter plates are commonly used as the standard bioreactor system for adhesion and biofilm formation of bacteria isolated from many different environments (Simões et al., 2010a; Moreira et al., 2013). Negative control wells contained MHB without bacterial cells. The plates were incubated for $24 \mathrm{~h}$ at $30{ }^{\circ} \mathrm{C}$ and agitated at $150 \mathrm{rpm}$. The prevention and control activities of PITC were tested as well as the cell adaptation to this product. Table 1 provides a schematic explanation of the biofilm tests.

\section{Table 1}

Scheme of the strategies developed for each sequence of tests (A, B, C and D) in order to characterize the activity of PITC on E. coli and S. aureus biofilm formation and control.

\begin{tabular}{|c|c|c|c|c|}
\hline \multirow[t]{2}{*}{ Test } & \multirow[t]{2}{*}{ Goal } & $\begin{array}{l}1^{\text {st }} \text { step:overnight } \\
\text { planktonic growth }\end{array}$ & $\begin{array}{l}2^{\text {nd }} \text { step: biofilm } \\
\text { formation in } \\
\text { microtiter plates }\end{array}$ & \multirow[t]{2}{*}{$\begin{array}{l}3^{\text {rd }} \text { step: exposure } \\
(1 \mathrm{~h}) \text { of } 24 \mathrm{~h} \text { aged } \\
\text { biofilms to PITC }\end{array}$} \\
\hline & & PITC & PITC & \\
\hline A & Biofilm prevention with PITC & $\mathrm{N}$ & $\mathrm{Y}$ & N.A \\
\hline B & $\begin{array}{l}\text { Adaptation ability of } \\
\text { planktonic cells to PITC and } \\
\text { biofilm formation }\end{array}$ & $\mathrm{Y}$ & $\mathrm{N}$ & N.A \\
\hline C & $\begin{array}{l}\text { Biofilm control activity of } \\
\text { PITC }\end{array}$ & $\mathrm{N}$ & $\mathrm{N}$ & $\mathrm{Y}$ \\
\hline $\mathrm{D}$ & $\begin{array}{l}\text { Control activity of biofilms } \\
\text { formed with planktonic cells } \\
\text { grown in the presence of } \\
\text { PITC }\end{array}$ & $\mathrm{Y}$ & $\mathrm{N}$ & $\mathrm{Y}$ \\
\hline
\end{tabular}




\subsubsection{Biofilm prevention activity of PITC (A)}

To assess the ability of PITC to prevent biofilm formation, overnight $(16 \mathrm{~h})$ cell suspensions (1 $\times 10^{8}$ cells $\left.\mathrm{mL}^{-1}\right)$, grown as described above, were added to 96 -well polystyrene microtiter plates. PITC at MIC and $5 \times$ MIC was also added to each well (10\% v/v of the well e $20 \mu \mathrm{L})$ along with the cells $(180 \mu \mathrm{L})$. The plates were incubated for $24 \mathrm{~h}$ at $30{ }^{\circ} \mathrm{C}$ and agitated at $150 \mathrm{rpm}$. Those cells were characterized regarding their ability to form biofilms in the presence of PITC in microtiter plates.

\subsubsection{Cell adaptation to PITC (B)}

Planktonic cells of $E$. coli and S. aureus were grown overnight (16 h) with MHB supplemented with PITC (at MIC and $5 \times \mathrm{MIC}$ ), at $30^{\circ} \mathrm{C}$ and $150 \mathrm{rpm}$. Afterwards, bacterial cultures were adjusted to a cell density of $1 \times 10^{8}$ cells $\mathrm{mL}^{-1}$. These bacteria were tested in their ability to form biofilms in 96-well polystyrene microtiter plates. Biofilms were allowed to grow for $24 \mathrm{~h}$ at $30{ }^{\circ} \mathrm{C}$ and under a constant agitation of $150 \mathrm{rpm}$. Those cells were characterized regarding their ability to form biofilms after being in contact with PITC for a long period.

\subsubsection{Biofilm control activities ( $C$ and $D)$}

Two tests were performed to assess the ability of PITC to control (remove and inactivate) biofilms. In $\mathrm{C}$, overnight cultures $\left(1 \times 10^{8}\right.$ cells $\left.\mathrm{mL}^{-1}\right)$ were added to microtiter plates to form biofilms during $24 \mathrm{~h}$. Afterwards, the medium was removed and the biofilms were exposed to PITC (at MIC and $5 \times \mathrm{MIC}$ ) for $1 \mathrm{~h}$, according to Simões et al. (2010b). This test allowed the assessment of the removal and inactivation activities of PITC on biofilms of E. coli and S.aureus.

In D, overnight cultures (16 h) grown with PITC (at MIC and $5 \times$ MIC) were used to form $24 \mathrm{~h}$ aged biofilms, similarly to test B. These biofilms were exposed to PITC (at MIC and $5 \times$ MIC) for $1 \mathrm{~h}$. This test (D) demonstrates the action of PITC on the removal and inactivation activities of biofilms formed by planktonic bacteria grown in the presence of the chemical.

\subsection{Biofilm analysis}

The 24-h biofilms were analyzed regarding their biomass, metabolic activity, culturability and viability.

The amount of biofilm formed was quantified using crystal violet (CV; Merck, Portugal) staining, according to Simões et al.(2010b). CV is a basic dye which binds to negatively charge surface molecules and polysaccharides in the extracellular matrix in both live and dead cells (Peeters et al., 2008; Extremina et al., 2011). The absorbance was measured at $570 \mathrm{~nm}$ using a microplate reader (Spectramax M2e, Molecular Devices, Inc.). Three independent experiments were performed for all the described tests.

Alamar blue is a redox indicator that can be reduced to pink by viable bacteria in the biofilm (Extremina et al., 2011). Thus, the extension of conversion from blue to pink is a reflection of cell viability. The modified alamar blue (7-hydroxy-3H-phenoxazin-3- one-10-oxide; Sigma, Portugal) microtiter plate assay was applied to determine the bacterial metabolic activity of the cells as reported by Sarker et al. (2007). For the staining procedure, fresh MHB (190 $\mu \mathrm{L})$ and 10 $\mu \mathrm{L}$ of alamar blue $(400 \mu \mathrm{M})$ indicator solution were added to each well. Plates were incubated 
for $20 \mathrm{~min}$ in darkness and at room temperature. Fluorescence was measured at $\lambda$ excitation= $570 \mathrm{~nm}$ and $\lambda_{\text {emission }}=590 \mathrm{~nm}$ with a microplate reader (Spectramax M2e). Stock solutions of alamar blue were stored at $-20^{\circ} \mathrm{C}$.

PITC effectiveness (biofilm mass and activity reduction) was assessed as follows: biofilm removal/inactivation $(\%)=\left(X_{\text {control }}\right.$ e $\left.X_{\text {PITC }}\right) /\left(X_{\text {control }}\right.$ e $\left.X_{\text {blank }}\right) \times 100$ where $X_{\text {control indicates the }}$ average absorbance/fluorescence for the control wells (untreated biofilms), and $X_{\text {PITc indicates }}$ the average absorbance/fluorescence for the PITC-treated wells (Simões et al., 2010b). Biofilms were scraped and diluted in saline solution and culturability of biofilm cells was assessed in PCA (Merck, Portugal). The number of colony forming units (CFU) was counted for plates with $>10$ and $<300$ colonies. The total CFU per sample was determined after overnight incubation at $30^{\circ} \mathrm{C}$ by correcting the colony count for the dilution factor.

The viability of biofilms was also assessed using the Live/Dead (L/D) BacLight bacterial viability kit. The Live/Dead BacLight ${ }^{\top M}$ kit (Invitrogen) is a fast method applied to estimate both viable and total counts of bacteria (Ferreira et al., 2011). The kit consists of two stains, propidium iodide (PI) and SYTO 9 ${ }^{\mathrm{TM}}$, which both stain nucleic acids. Three hundred microliters of each biofilm suspension were filtered through a Nucleopore ${ }^{\circledR}$ (Whatman) black polycarbonate membrane (pore size $0.22 \mu \mathrm{m}$ ) and stained with SYTO $9^{\text {TM }}$ and PI according to the instructions provided by the manufacturer. The microscope used to observe stained bacteria was a LEICA DMLB2 with a mercury lamp HBO/100W/3 incorporating a CCD camera to acquire images using IM50 software (LEICA) and a $100 \mathrm{x}$ oil immersion fluorescence objective. The optical filter combination for optimal viewing of stained mounts consisted of a 480-500 nm excitation filter in combination with a $485 \mathrm{~nm}$ emission filter (Chroma 61000-V2 DAPI/FITC/TRITC). The numbers of bacteria were estimated from counts of, at least, 20 microscopic fields using three replicates for each sample. The number of live (green) and dead (red) cells was calculated as follows: $N=$ $(n \times A) /(a \times V)$, where $N=$ cells $\mathrm{mL}^{-1} ; n=$ the average number of cells per microscopic field; $A=$ filtration area $\left(\mathrm{mm}^{2}\right) ; a=$ microscopic field area $\left(\mathrm{mm}^{2}\right) ; \mathrm{V}=$ volume of filtered sample $(\mathrm{mL})$. The results for viable cells and CFU were expressed as the log reduction, defined as the negative $\log _{10}$ of the quotient of the number of CFU/viable cells before and after the exposure to PITC. A positive log reduction represents a decrease in the number of CFU.

\subsection{Statistical analysis}

The data were analyzed using the statistical program SPSS version 19.0 (Statistical Package for the Social Sciences). Because low sample numbers contribute to uneven variation, the adhesion results were analyzed by the nonparametric Wilcoxon test. Statis-tical calculations were based on a confidence level $>95 \%(P<0.05)$ which was considered statistically significant. The results were presented as the means \pm SEM (standard error of the mean). 


\section{Results}

The MIC of PITC was found to be $1000 \mu \mathrm{g} \mathrm{mL}^{-1}$ for both bacteria. Further experiments were performed with PITC at MIC and $5 \times$ MIC.

In order to predict the ability of the microorganisms to adhere to PS surfaces, the free energy of interaction between the bacteria and the surface, when immersed in water, was calculated. According to this approach, the adhesion of both bacteria to the surface was thermodynamically unfavorable $\Delta G_{b w s}^{T O T}>0 \mathrm{~mJ} \mathrm{~m}^{-2}$ ) (Table 2).

Table 2

Free energy of adhesion $\left(\Delta G_{b w s}^{T O T}\right)$ of untreated and PITC treated cells to PS.

\begin{tabular}{ll}
\hline PTIC $(\mu \mathrm{g} / \mathrm{mL})$ & $\begin{array}{l}\text { Free energy of adhesion }(\mathrm{mJ} \\
\left.\mathrm{m}^{-2}\right)-\Delta G_{b w s}^{T O T}\end{array}$ \\
\hline E. coli & $6.4 \pm 0.3$ \\
0 & $9.6 \pm 0.5$ \\
MIC & $10.6 \pm 1.1$ \\
$5 \times$ MIC & \\
S. aureus & \\
0 & $2.4 \pm 0.4$ \\
MIC & $3.5 \pm 0.1$ \\
$5 \times$ MIC & $8.0 \pm 0.7$ \\
\hline$\Delta G_{b w s}^{T O T}<0 \mathrm{~mJ} \mathrm{~m}^{-2}-$ thermodynamically favorable adhesion; $\Delta G_{b w s}^{T O T}>0 \mathrm{~mJ} \mathrm{~m}^{-2}-$ thermodynamically unfavorable adhesion
\end{tabular}

S. aureus had a lower free energy of adhesion $(P<0.05)$, and therefore its adhesion to PS should be more favorable when compared to $E$. coli. In the presence of PITC, bacteria had lower ability to adhere to PS, especially when PITC was applied at $5 \times$ MIC $(P<0.05)$.

The interference of PITC on the swimming and swarming motilities of $E$. coli and sliding motility of $S$. aureus was investigated. Swimming motility was the most significant type of motility found for $E$. coli $(P<0.05)$ with an increase up to $48 \mathrm{~h}(\mathrm{P}<0.05)$. Swarming motility remained very low over time. For $S$. aureus, sliding motility increased up to $72 \mathrm{~h}(\mathrm{P}<0.05)$. With PITC at MIC, swimming and sliding motilities were reduced to almost $90 \%$ for $E$. coli and $70 \%$ for $S$. aureus, respectively, after $24 \mathrm{~h}$. However, both motilities increased in the last $24 \mathrm{~h}$, especially for $E$. coli. With PITC at $5 \times$ MIC, both motilities were completely inhibited for E. coli. For S. aureus, the sliding motility remained very low (Table 3 ). 


\section{Table 3}

Motility (swimming, swarming and sliding) results $(\mathrm{mm})$ for bacteria with and without PITC at sampling time (h). A volume of $15 \mu \mathrm{L}$ of bacterial culture produced an $8 \mathrm{~mm}$ (baseline) spot on the agar.

\begin{tabular}{|c|c|c|c|}
\hline & \multicolumn{2}{|l|}{ E. coli } & \multirow{2}{*}{$\begin{array}{l}\text { S. aureus } \\
\text { Sliding }\end{array}$} \\
\hline & Swimming & Swarming & \\
\hline \multicolumn{4}{|c|}{ Control } \\
\hline $24 \mathrm{~h}$ & $55 \pm 4.6$ & $8.0 \pm 0.0$ & $25 \pm 0.6$ \\
\hline $48 \mathrm{~h}$ & $85 \pm 1.0$ & $8.0 \pm 0.0$ & $60 \pm 0.0$ \\
\hline $72 \mathrm{~h}$ & $85 \pm 0.0$ & $9.0 \pm 0.5$ & $65 \pm 0.6$ \\
\hline \multicolumn{4}{|c|}{ PITC (MIC) } \\
\hline $24 \mathrm{~h}$ & $8.0 \pm 0.0$ & $8.0 \pm 0.0$ & $8.0 \pm 0.0$ \\
\hline $48 \mathrm{~h}$ & $10 \pm 0.5$ & $9.0 \pm 0.3$ & $10 \pm 0.0$ \\
\hline $72 \mathrm{~h}$ & $48 \pm 2.5$ & $9.0 \pm 0.0$ & $14 \pm 1.0$ \\
\hline \multicolumn{4}{|c|}{$\operatorname{PITC}(5 \times \mathrm{MIC})$} \\
\hline $24 \mathrm{~h}$ & - & - & $9.0 \pm 0.0$ \\
\hline $48 \mathrm{~h}$ & - & - & $9.0 \pm 0.0$ \\
\hline $72 \mathrm{~h}$ & - & - & $9.0 \pm 0.0$ \\
\hline
\end{tabular}

The effects of PITC at MIC and $5 \times$ MIC in prevention and control of $E$. coli and S. aureus biofilms were evaluated. Fig. 2 presents the biomass and activity reductions (\%) of the biofilms caused by PITC at MIC and $5 \times$ MIC. Fig. 3 presents the number of total and viable cells obtained with L/D assays and of CFU for biofilms of $E$. coli and $S$. aureus. The viable counts for biofilms nonexposed to PITC were $9.7 \times 10^{7}$ and $7.1 \times 10^{7}$ cells $\mathrm{mL}^{-1}$ for E. coli and S. aureus, respectively; the CFUs of these biofilms were $7.8 \times 10^{7}$ and $5.8 \times 10^{7} \mathrm{CFU} \mathrm{mL} \mathrm{m}^{-1}$ for $E$. coli and S. aureus, respectively. Table 4 presents the log 10 reduction of the number of viable cells and CFU after exposure to PITC. 

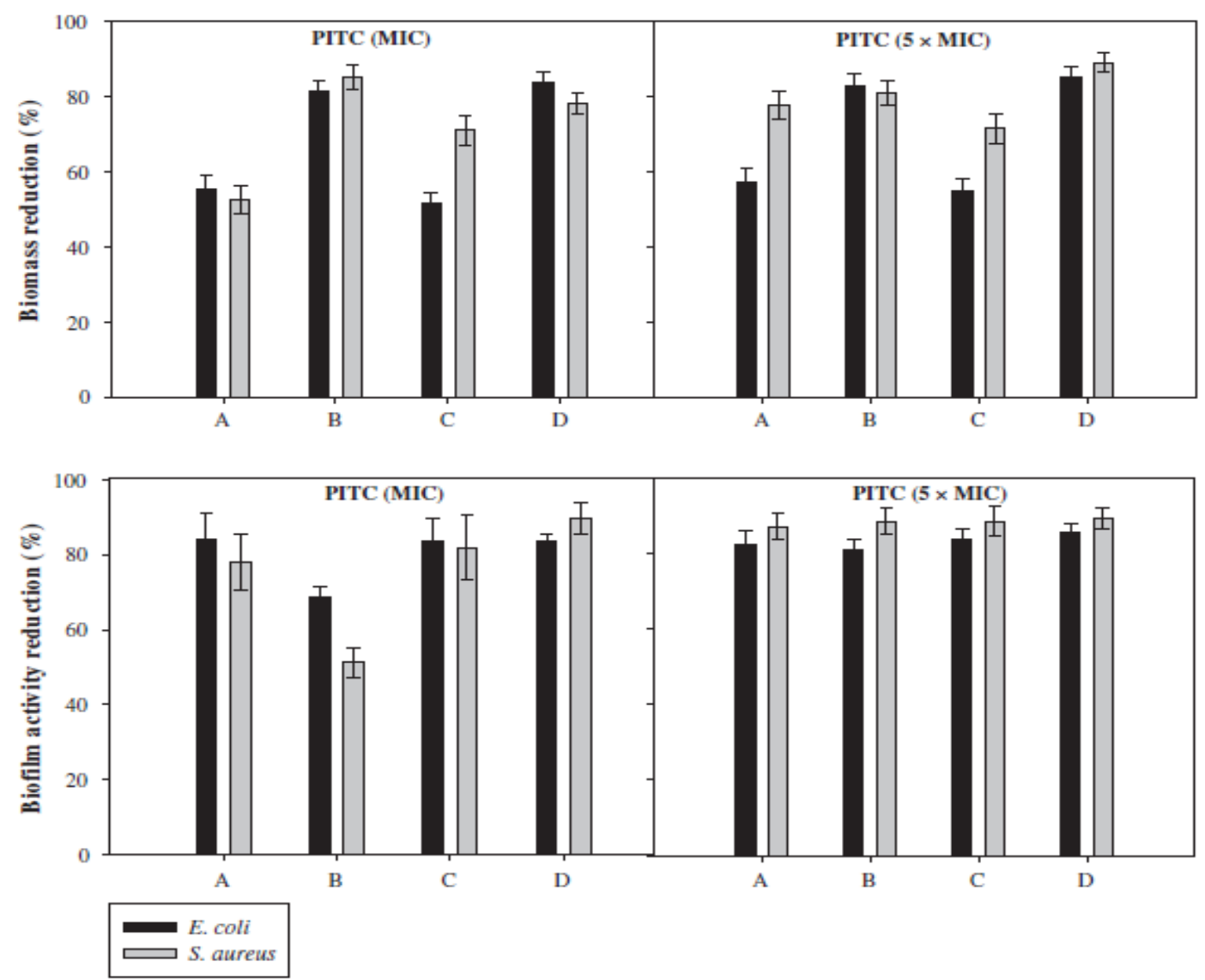

Fig. 2. Percentages of biomass removal and biofilm activity reduction for $E$. coli (black columns) and S. aureus (gray columns) biofilms after exposure to PITC at MIC and $5 \times$ MIC. A - preventive action of PITC, B - adaptation ability of planktonic cells to PITC; C - removal/inactivation activity of PITC on biofilms; D - removal/inactivation activity of PITC on biofilms previously exposed to this chemical. Mean values \pm standard deviation for three replicates are illustrated. 


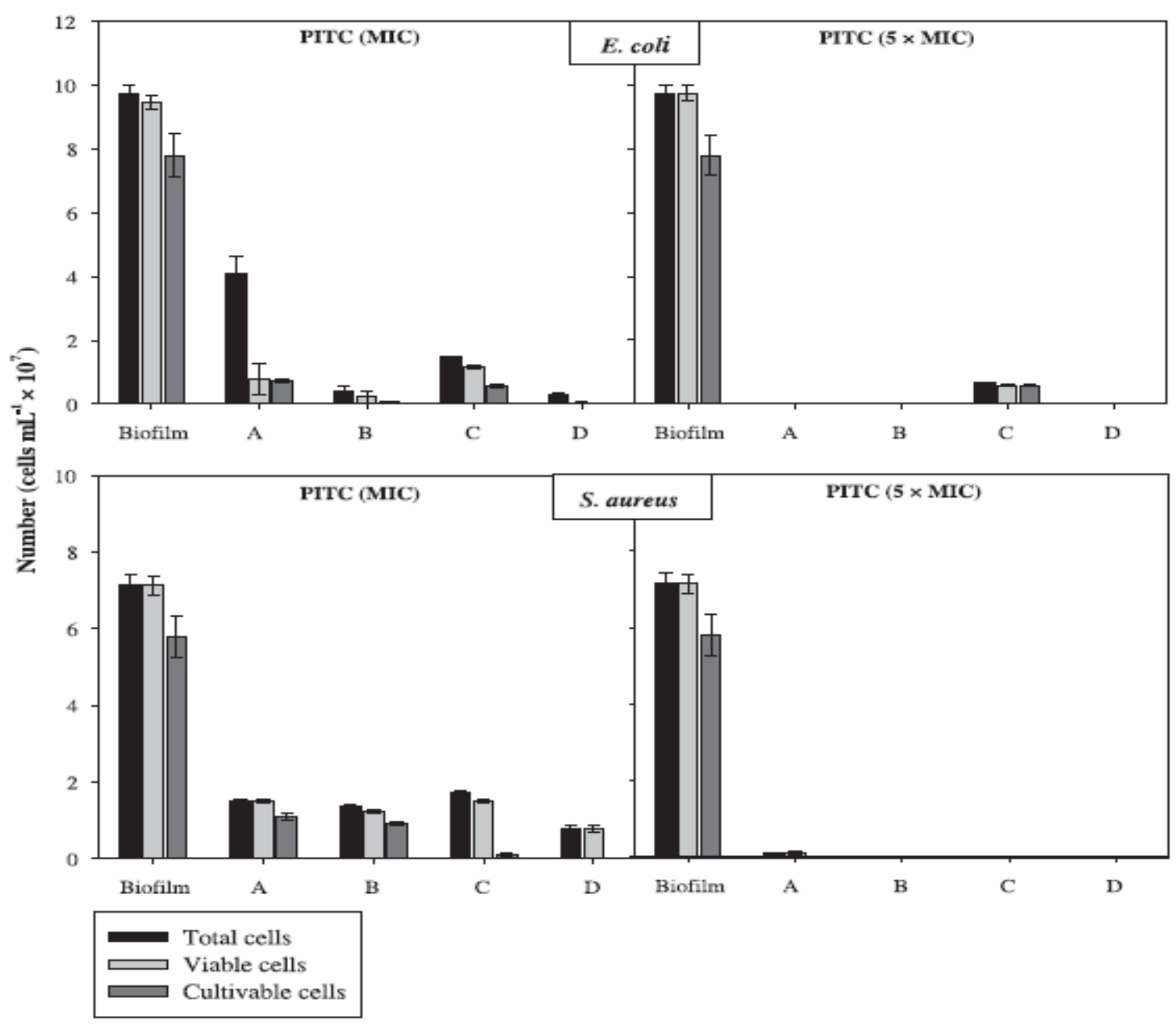

Fig. 3. Number of total, viable and culturable cells of $E$. coli (top) and $S$. aureus (bottom) control biofilm and after exposure to PITC at MIC and $5 \times$ MIC. Biofilm e positive growth control, A preventive action of PITC, B - adaptation ability of planktonic cells to PITC; C removal/inactivation activity of PITC on biofilms; D - removal/inactivation activity of PITC on biofilms previously exposed to this chemical. Mean values \pm standard deviation for three replicates are illustrated.

In order to ascertain the potential of PITC in biofilm prevention, biofilms were formed in microtiter plates in the presence of PITC (test A). With PITC at MIC, the amount of biofilm biomass (Fig. 2) obtained for $E$. coli and $S$. aureus was reduced $55.3 \%$ and $52.6 \%$, respectively; and the metabolic activity was reduced $83.8 \%$ and $77.9 \%$, respectively. Both L/D and culturability assays show 1.1 and $0.7 \log _{10}$ reductions of viable cells for $E$. coli and $S$. aureus, respectively (Table 4). In the presence of PITC at $5 \times$ MIC, the biofilm mass and activity were not significantly reduced (Fig. 2). The only improvement in biofilm prevention at this concentration of PITC was obtained with the reduction of the number of viable cells and CFU (4.0 and $1.9 \log _{10}$ reduction and 4.4 and $2.8 \log _{10}$ reduction for $E$. coli and $S$. aureus, respectively) $(P<0.05)$. This result shows that PITC disturbed the formation of biofilms which was in part already suggested by the results of the free energy of adhesion (Table 2).

With the purpose of evaluating the adaptation capacity of cells to PITC, overnight cultures 
supplemented with PITC were grown and the ability of these cells to form biofilm was assessed (test B). The results in Fig. 2 show that overnight incubation with PITC at MIC did not kill all the bacteria and that the surviving cells can form biofilms (reduction of biomass formation of $81.3 \%$ and $85.2 \%$ for $E$. coli and $S$. aureus, respectively). A significant proportion of bacteria remained viable after treatment at this concentration of PITC: 68.6 and $51.2 \%$ of viable cells for $E$. coli and S. aureus, respectively (Fig. 3). With PITC at $5 \times$ MIC, the reduction of the number of both viable cells and CFU was very high (Fig. 3). Table 4 shows a 4.2 and $3.4 \log _{10}$ reduction of viable cells and 4.9 and $3.1 \log _{10}$ reduction of CFU for $E$. coli and $S$. aureus, respectively at this concentration. The capacity of PITC to act against biofilms was also evaluated (test C). The percentages of biofilm removal $1 \mathrm{~h}$ after treatment with PITC at MIC were considerable $(51.5 \%$ and $71.0 \%$ for $E$. coli and S. aureus, respectively; Fig. 2). Biofilm activity assays show a decrease of metabolic activity of $83.5 \%$ and $81.9 \%$ for E. coli and S. aureus, respectively (Fig. 2). However, the $\log _{10}$ reduction of viable cells is low at this concentration $(0.9$ and 0.7 for $E$. coli and $S$. aureus, respectively) (Table 4). With PITC at $5 \times$ MIC, a greater effect was obtained with the reduction of viability for $S$. aureus (with a $\log _{10}$ reduction of viable cells of 3.0 and a $\log _{10}$ reduction of CFU of 3.1) (Table 4).

\section{Table 4}

$\log _{10}$ reduction in the number of viable cells and CFU after exposure of PITC. A - preventive action of PITC, B - adaptation capacity of cells to PITC; C - removal/inactivation activity of PITC on biofilms; D - removal/inactivation activity of PITC on biofilms previously exposed to this compound. Mean values \pm standard deviation are illustrated.

\begin{tabular}{|c|c|c|c|c|c|c|c|c|}
\hline & \multicolumn{4}{|c|}{$\log _{10}$ viable cells reduction } & \multicolumn{4}{|c|}{$\log _{10}$ CFU reduction } \\
\hline & A & B & C & D & A & B & C & D \\
\hline \multicolumn{9}{|l|}{ E. coli } \\
\hline PITC (MIC) & $1.1 \pm 0.5$ & $1.6 \pm 0.1$ & $0.9 \pm 0.3$ & $2.4 \pm 0.4$ & $1.0 \pm 0.2$ & $1.9 \pm 0.5$ & $1.1 \pm 0.2$ & \multirow{2}{*}{$2.4 \pm 0.1$} \\
\hline $\operatorname{PITC}(5 \times$ MIC $)$ & $4.0 \pm 0.5$ & $4.2 \pm 0.6$ & $1.2 \pm 0.3$ & $4.5 \pm 0.5$ & $4.4 \pm 0.2$ & $4.9 \pm 0.7$ & $1.1 \pm 0.1$ & \\
\hline \multicolumn{9}{|l|}{ S. aureus } \\
\hline PITC (MIC) & $0.7 \pm 0.1$ & $0.8 \pm 0.2$ & $0.7 \pm 0.1$ & $1.0 \pm 0.4$ & $0.7 \pm 0.2$ & $0.8 \pm 0.3$ & $1.8 \pm 0.2$ & \multirow{2}{*}{$\begin{array}{l}2.3 \pm 0.2 \\
\mathrm{a}\end{array}$} \\
\hline PITC $(5 \times$ MIC $)$ & $1.9 \pm 0.4$ & $3.4 \pm 0.5$ & $3.0 \pm 0.3$ & $4.0 \pm 0.3$ & $2.8 \pm 0.4$ & $3.1 \pm 0.4$ & $3.1 \pm 0.2$ & \\
\hline
\end{tabular}

a Total growth inhibition.

Test D evaluates the antimicrobial capacity of PITC on biofilms formed by cells previously exposed to PITC. With PITC at MIC, biofilm mass reduction was $84.0 \%$ and $78.2 \%$ for $E$. coli and S. aureus, respectively (Fig. 2). Biofilm activity reduction was $83.6 \%$ and $89.7 \%$ for $E$. coli and $S$. aureus, respectively (Fig. 2). Moreover, the viable cell $\log _{10}$ reduction was 2.4 and 1.0 and the CFU $\log _{10}$ reduction was 2.4 and 2.3 (Table 4) for $E$. coli and $S$. aureus, respectively (the highest reductions obtained when compared to other tests at this concentration of PITC-P < 0.05). With PITC at $5 \times$ MIC, biofilm mass reductions were $85.4 \%$ and $89.1 \%$ for $E$. coli and $S$. aureus, respectively (Fig. 2). These removal percentages were the highest compared with the other tests $(P<0.05)$. Biofilm activity reductions were also very high: $85.4 \%$ and $89.1 \%$ for $E$. coli and $S$. aureus, respectively (Fig. 2). Table 4 shows that this test promoted the highest $\log _{10}$ reductions of the number of viable cells ( 4.5 and 4.0 for $E$. coli and $S$. aureus, respectively) and complete elimination of CFU. 


\section{Discussion}

The ability of microorganisms to attach and grow on food-contact surfaces and on manufacturing and processing facilities is a considerable hazard for food industries (Bessen, 2009; Chorianopoulos et al., 2011). Disinfection is regarded as a crucial step to eliminate microbial contaminants, avoiding the adulteration of raw materials and products (Zottola and Sasahara, 1994; Meyer, 2006; Chorianopoulos et al., 2011). However, due to the ability of microorganisms to resist disinfection, particularly when they form biofilms, new antimicrobial strategies are required.

In order to reach high killing rates and to avoid resistance and adaptation problems, disinfectants are in general used at very high concentrations relative to their MICs (Chapman, 2003; Meyer, 2006). In this study, PITC was tested at the MIC and $5 \square$ MIC. To develop efficient biofilm preventive and control strategies, it is necessary to understand the bacterial adhesion process (Simões et al., 2010a). It has been reported that, in addition to the antimi-crobial effects, the action of ITCs on sessile organisms may involve a direct effect on adhesion and cause disruption of membrane-surface adhesion (Gomes de Saravia and Gaylarde, 1998). In bio-logical systems, hydrophobic interactions are usually the strongest of all long-range non-covalent forces, and adhesion to surfaces is often mediated by this type of interactions (Cerca, 2006). Cell-PITC interaction results in an alteration of the cell surface hydropho-bicity (increase of the hydrophilic character) (Abreu et al., 2012a), which has a negative effect on cell adhesion to PS. Despite the unfavorable thermodynamic value (DGTOTbws $>0 \mathrm{mJm} \square 2$ ) bacteria adhered to PS and biofilms were formed. Hence, the comparison between the theoretical thermodynamic adhesion evaluation and the adhesion assays reinforces that the last is underestimated when only based on thermodynamic approaches. Moreover, thermody-namic adhesion and in vitro bacterial adhesion and biofilm for-mation results for $\mathrm{E}$. coli and S. aureus were contradictory. The correlation between cell surface hydrophobicity and bacterial adhesion has been found by some authors (Dickson and Koohmaraie, 1989; Pompilio et al., 2008) but not by others (Cerca, 2006; Li and McLandsborough, 1999; O'Toole et al., 2000; Simões et al., 2007, 2010a). Moreover, it was found that the tested bacte-ria were negatively charged (Abreu et al., 2012a), as well as PS (Simões et al., 2010a), and therefore, based only on the DLVO (Derjaguin, Landau, Verwey and Overbeek) theory, the electrostatic forces between the microorganisms and the surfaces of accession would be repulsive (Simões et al., 2010a) and could prevent cell adhesion to PS. Nevertheless, other authors already observed thecolonization of negatively charged surfaces by microorganisms with the same charge (van Loosdrecht et al., 1987). In this context, the presence of extracellular biological molecules such as pili, flagella and fimbriae and the expression of extracellular append-ages (adhesins), which mediate specific nanoscale interactions with the substratum, plays an integral role on initial adhesion to a sur-face and biofilm formation (Simões et al., 2007, 2010a). These bio-logical factors may be important in the adhesion process helping to overcome the repulsive forces associated with the substratum (Pompilio et al., 2008).

Bacterial motility also has a great influence on adhesion and biofilm formation processes. E. coli has two flagella-driven motility types: swimming (flagella-directed movement in aqueous environments) and swarming (flagella-directed rapid movement onto solid surfaces). Although staphylococci do not have flagella, they can spread on solid surfaces via a mechanism called colony spreading or sliding. The sliding ability of these bacteria is enabled by the expansive forces of a growing culture in combination with special surface properties of the cells resulting in reduced friction between the cell and its substrate (Kaito and Sekimizu, 2007). With PITC at MIC, the swimming and sliding motilities were significantly reduced $24 \mathrm{~h}$ after incubation. However, the 
bacteria recovered motility after a long exposure period. With PITC at $5 \square$ MIC, bac-terial motility was completely inhibited for $\mathrm{E}$. coli. This effect is probably related with the antimicrobial effects of PITC at the con-centration tested. S. aureus sliding motility remained very low over time. Some authors allege the importance of cells motility to form biofilms and report that motile bacteria attach to surfaces more rapidly than nonmotile strains (Korber et al., 1989; Lemon et al., 2007). However, other authors disagree over the role of surface structures since nonfimbriated and nonflagellated cells can attach at rates similar to the same cells possessing these structures (Dickson and Koohmaraie, 1989). In this study, the comparison between motility inhibition with PITC and bacterial adhesion and biofilm formation proposes that the inhibition of swarming and swimming motilities for E. coli and sliding motility for $\mathrm{S}$. aureus may hinder their ability to form biofilms.

The effects of PITC at MIC and $5 \square$ MIC on E. coli and S. aureus biofilms were characterized by biomass and activity reductions (\%) and the number of viable cells obtained with $L / D$ assays and of CFU. There was no consistency $(P<0.05)$ between the CFU counts and the number of viable cells for most of the experiments. A possible explanation is the presence of injured or starved cells or potentially 'viable but nonculturable' cells (VBNC) that may not be able to initiate cell division at a sufficient rate to form colonies (Lüthje and Schwarz, 2006; Ferreira et al., 2011). Moreover, some biofilm cul-turability and viability results obtained after disinfection are not equivalent to those obtained by $C V$ and alamar blue staining $(P<0.05)$. This is expected due to the limitations of the methods. For example, CFU counts are known to be inefficient in the detection of disinfectant-injured bacteria and can overestimate disin-fection. However, some authors argue that they could be used as a general indicator that demonstrates the efficiency of disinfection (Vapnek and Spreij, 2005; Simões et al., 2010b). On the other hand, many red cells scored as 'dead' in the BacLight assay may be able to recover and reproduce under certain conditions (Mauriello et al., 2005). Thus, it is essential to combine several methodologies to overcome these method limitations and ensure more complete information about the action of biocides on bacteria.

The experiments with PITC demonstrate that this compound disturbed the formation of biofilms (test A), the overnight incuba-tion with PITC at MIC did not kill all the bacteria and the surviving cells can form biofilms (test B). In test C, even though PITC could kill a significant portion of cells, part of the biofilms were still attached to the surface and were viable. Also, the results suggest that a second exposure of bacteria to PITC has a positive effect against bacteria previously exposed to this compound (test D). Regardless the great effect obtained with PITC against biofilms, experiments with planktonic cells cannot be taken as reference to develop bio-film prevention and control strategies. Even at the highest con-centration, PITC could not totally prevent biofilm development neither could completely remove/inactivate them. This suggests that growth inhibition by itself is not a reliable indicator for the inability of bacteria to form a biofilm.

One strategy to prevent the formation of biofilms is to disinfect regularly, before biofilm formation starts. However, in the food industry, it is hardly possible to disinfect frequently enough to avoid this initial step (Meyer, 2003). So, it is important to use a disinfectant capable of acting in both situations: prevention of biofilm formation and removal of established biofilms. In this study, we found that PITC can act in both instances as it prevented biofilm formation, acting in motility and adhesion, and removed and inactivated biofilms. Also, it is possible to establish a relationship between cell motility, surface characteristics and their influence on the adhesion capacity of bacteria. The disturbance of both factors coincided with a decrease in biofilm formation. Moreover, since the chemical composition of the matrix of extracellular polymeric substances varies significantly from biofilm to biofilm (Meyer, 2003), the nonspecific mechanism of action of ITCs on multiple proteins and enzymes makes it suitable for acting on different kinds of biofilms (Simões 
et al., 2010c).

ITCs are regarded as the most biocidal products of all GHP (Morra and Kirkegaard, 2002) and can inhibit a wide variety of plant pests including mammals, birds, insects, molluscs, aquatic invertebrates, nematodes, bacteria and fungi (Borek et al., 1995; Sarwar et al., 1998; Morra and Kirkegaard, 2002; Norsworthy and Meehan, 2005; Halkier and Gershenzon, 2006; Saavedra et al., 2010). Some ITCs were also found to be effective inhibitors of the in vitro growth of Gramnegative and Gram-positive pathogenic bacteria and to act synergistically with less efficient products to control bacterial growth (Saavedra et al., 2010). Accordingly, it would be interesting to continue the study of PITC and other ITCs, natural and synthetic, as antimicrobial products alone or in com-bination with common disinfectants, as a resistance modifying agent (Abreu et al., 2012b). Moreover, additional safety information is needed for the immediate use of PITC as antiseptic and disin-fectant. The European Food Safety Authority (EFSA) Panel on Food Additives and Nutrient Sources added to Food (ANS) provided a scientific opinion on the safety of the ITC allyl isothiocyanate for the use as a food additive, proposing that no significant safety concerns are expected with its use as anti-spoilage agent (European Food Safety Authority - EFSA, 2010).

\section{Conclusions}

In current industrial processes, pathogens are displaying an increasingly higher capacity to survive after apparently effective cleaning and disinfection programmes. Many antimicrobials are losing their effectiveness as a consequence of their extensive and, often inappropriate use, allowing microorganisms to develop resistance. The use of plants as a source of new antimicrobials can be an attractive strategy to control microbial growth and biofilms. The results from this study showed that PITC, a synthetic ITC, had significant antimicrobial activity on E. coli and $\mathrm{S}$. aureus planktonic and biofilm cells. Biofilm cells usually exhibit increased tolerance to antimicrobials. However, PITC demonstrated potential to inhibit cell motility, affect cell adhesion to polystyrene and to prevent and efficiently control biofilms of the selected bacteria. This study with PITC also highlights the importance of exploring plants and other natural sources for effective antimicrobial agents and/or scaffold structures.

\section{Acknowledgments}

This work was supported by Operational Programme for Competitiveness Factors e COMPETE and by FCT e Portuguese Foundation for Science and Technology through Projects Bioresist PTDC/EBB-EBI/105085/2008; Phytodisinfectants e PTDC/DTP-SAP/ 1078/2012 and the PhD grants awarded to Ana Abreu (SFRH/BD/ 84393/2012) and Anabela Borges (SFRH/BD/63398/2009). 


\section{References}

Abreu, A.C., Borges, A., Simões, L.C., Saavedra, M.J., Simões, M., 2012a. Antimicrobial activity of phenyl isothiocyanate on Escherichia coli and Staphylococcus aureus. Medicinal Chemistry. [Epub ahead of print].

Abreu, A.C., McBain, A.J., Simões, M., 2012b. Plants as sources of new antimicrobials and resistance-modifying agents. Natural Product Reports 29, 1007-1021.

Amorena, B., Gracia, E., Monzón, M., Leiva, J., Oteiza, C., Pérez, M., Alabart, J.-L., Hernández-Yago, J., 1999. Antibiotic susceptibility assay for Staphylococcus aureus in biofilms developed in vitro. Journal of Antimicrobial Chemotherapy 44, 43-55.

Bermúdez-Aguirre, D., Barbosa-Cánovas, G.V., 2012. Disinfection of selected vegetables under nonthermal treatments: chlorine, acid citric, ultraviolet light and ozone. Food Control 29, 82-90.

Bessen, D.E., 2009. Population biology of the human restricted pathogen, Streptococcus pyogenes. Infection, Genetics and Evolution 9, 581-593.

Borek, V., Elberson, L.R., McCaffrey, J.P., Morra, M.J., 1995. Toxicity of aliphatic and aromatic isothiocyanates to eggs of the black vine weevil (Coleoptera: Curcu- lionidae). Journal of Economic Entomology 88, 1192-1196.

Borges, A.S., Simões, L.C., Saavedra, M.J., Simões, M., 2013. The action of selected isothiocyanates on bacterial biofilm prevention and control. International Biodeterioration \& Biodegradation 86, 25-33.

Busetti, A., Crawford, D.E., Earle, M.J., Gilea, M.A., Gilmore, B.F., Gorman, S.P., Laverty, G., Lowry, A.F., McLaughlin, M., Seddon, K.R., 2010. Antimicrobial and antibiofilm activities of 1-alkylquinolinium bromide ionic liquids. Green Chemistry 12, 420-425.

Butler, M.T., Wang, Q., Harshey, R.M., 2010. Cell density and mobility protect swarming bacteria against antibiotics. Proceedings of the National Academy of Sciences of the United States of America 107, 3776-3781.

Cerca, N.M., 2006. Virulence Aspects of Staphilococcus Epidermis: Biofilm Formation and Poly-n-acetyl-glucosamine Production. University of Minho, Braga. PhD thesis.

Chapman, J.S., 2003. Disinfectant resistance mechanisms, cross-resistance, and coresistance. International Biodeterioration \& Biodegradation 51, 271-276.

Chorianopoulos, N.G., Tsoukleris, D.S., Panagou, E.Z., Falaras, P., Nychas, G.J.E., 2011. Use of titanium dioxide (TiO2) photocatalysts as alternative means for Listeria monocytogenes biofilm disinfection in food processing. Food Microbiology 28, 164-170.

CLSI, 2007. Clinical and Laboratory Standards Institute: Performance Standards for Antimicrobial Susceptibility Testing. document M2eA8. CLSI/NCCLS, West Valley Road, Pennsylvania, USA.

Cowan, M.M., 1999. Plant products as antimicrobial agents. Clinical Microbiology Reviews 12, 564-582.

Dangl, J.L., Jones, J.D.G., 2001. Plant pathogens and integrated defence responses to infection. Nature 411, 826-833. 
Dickson, J.S., Koohmaraie, M., 1989. Cell surface charge characteristics and their relationship to bacterial attachment to meat surfaces. Applied and Environ- mental Microbiology 55, 832-836.

Dixon, R.A., 2001. Natural products and plant disease resistance. Nature 411, 843e847. European Food Safety Authority (EFSA), 2010. Scientific Opinion on the Safety of Allyl Isothiocyanate for the Proposed Uses as a Food Additive. EFSA-Q-2009e 00377. EFSA Panel on Food Additives and Nutrient Sources Added to Food(ANS), Parma, Italy.

Extremina, C.I., Costa, L., Aguiar, A.I., Peixe, L., Fonseca, A.P., 2011. Optimization of processing conditions for the quantification of enterococci biofilms using microtitre-plates. Journal of Microbiological Methods 84, 167-173.

Fahey, J.W., Zalcmann, A.T., Talalay, P., 2001. The chemical diversity and distribution of glucosinolates and isothiocyanates among plants. Phytochemistry 56, 5-51.

Ferreira, C., Pereira, A.M., Pereira, M.C., Melo, L.F., Simões, M., 2011. Physiological changes induced by the quaternary ammonium compound benzyldimethyldodecylammonium chloride on Pseudomonas fluorescens. Journal of Antimicrobial and Chemotherapy 66, 1-8.

Gilbert, P., Maira-Litran, T., McBain, A.J., Rickard, A.H., Whyte, F.W., 2002a. The physiology and collective recalcitrance of microbial biofilm communities. Ad- vances in Microbial Physiology 46, 203-256.

Gilbert, P., Allison, D.G., McBain, A.J., 2002b. Biofilms in vitro and in vivo: do singular mechanisms imply cross-resistance? Journal of Applied Microbiology 92, 98S-110S.

Glinel, K., Jonas, A.M., Jouenne, T., Leprince, J.r.m., Galas, L., Huck, W.T.S., 2008. Antibacterial and antifouling polymer brushes incorporating antimicrobial peptide. Bioconjugate Chemistry 20, 71-77.

Gomes de Saravia, S.G., Gaylarde, C.C., 1998. The antimicrobial activity of an aqueous extract of Brassica negra. International Biodeterioration \& Biodegradation 41, 145-148.

Grönholm, L., Wirtanen, G., Ahlgren, K., Nordström, K., Sjöberg, A.M., 1999. Screening of antimicrobial activities of disinfectants and cleaning agents against foodborne spoilage microbes. Zeitschrift für Lebensmitteluntersuchung und- Forschung A 208, 289-298.

Halkier, B.A., Gershenzon, J., 2006. Biology and biochemistry of glucosinolates.Annual Review of Plant Biology 57, 303-333.

Inoue, T., Shingaki, R., Fukui, K., 2008. Inhibition of swarming motility of Pseudomonas aeruginosa by branched-chain fatty acids. FEMS Microbiology Letters 281, 8186.

Kaito, C., Sekimizu, K., 2007. Colony spreading in Staphylococcus aureus. Journal of Bacteriology 189, 2553-2557.

Korber, D.R., Lawrence, J.R., Sutton, B., Caldwell, D.E., 1989. Effect of laminar flow velocity on the kinetics of surface recolonization by Motp and Mot Pseudomonas fluorescens. Microbial Ecology 18, 1-19.

Kühn, K.P., Chaberny, I.F., Massholder, K., Stickler, M., Benz, V.W., Sonntag, H.-G., 
Erdinger, L., 2003. Disinfection of surfaces by photocatalytic oxidation with titanium dioxide and UVA light. Chemosphere 53, 71-77.

Langsrud, S., Sidhu, M.S., Heir, E., Holck, A.L., 2003. Bacterial disinfectant resistance e a challenge for the food industry. International Biodeterioration Biodegra- dation 51, 283290.

Lemon, K.P., Higgins, D.E., Kolter, R., 2007. Flagellar Motility is critical for Listeria monocytogenes biofilm formation. Journal of Bacteriology 189, 4418-4424.

Li, J., McLandsborough, L.A., 1999. The effects of the surface charge and hydro- phobicity of Escherichia coli on its adhesion to beef muscle. International Journal of Food Microbiology 53, 185-193.

Lüthje, P., Schwarz, S., 2006. Antimicrobial resistance of coagulase-negative staphylococci from bovine subclinical mastitis with particular reference to macrolideelincosamide resistance phenotypes and genotypes. Journal of Antimicrobial Chemotherapy 57, 966-969.

Mah, T.-F.C., O'Toole, G.A., 2001. Mechanisms of biofilm resistance to antimicrobial agents. Trends in Microbiology 9, 34-39.

Mauriello, G., De Luca, E., La Storia, A., Villani, F., Ercolini, D., 2005. Antimicrobial activity of a nisin-activated plastic film for food packaging. Letters in Applied Microbiology 41, 464469.

Meyer, B., 2003. Approaches to prevention, removal and killing of biofilms. International Biodeterioration \& Biodegradation 51, 249-253.

Meyer, B., 2006. Does microbial resistance to biocides create a hazard to food hygiene? International Journal of Food Microbiology 112, 275-279.

Moreira, J.M.R., Gomes, L.C., Araújo, J.D.P., Miranda, J.M., Simões, M., Melo, L.F., Mergulhão, F.J., 2013. The effect of glucose concentration and shaking conditions on Escherichia coli biofilm formation in microtiter plates. Chemical Engi- neering Science 94, 192-199.

Morra, M.J., Kirkegaard, J.A., 2002. Isothiocyanate release from soil-incorporated Brassica tissues. Soil Biology \& Biochemistry 34, 1683-1690.

Norsworthy, J.K., Meehan, J.T., 2005. Use of isothiocyanates for suppression of Palmer amaranth (Amaranthus palmeri ), pitted morningglory (Ipomoea lacu- nosa), and yellow nutsedge (Cyperus esculentus). Weed Science 53, 884-890.

O'Toole, G., Kaplan, H.B., Kolter, R., 2000. Biofilm formation as microbial develop- ment. Annual Review of Microbiology 54, 49-79.

Peeters, E., Nelis, H.J., Coenye, T., 2008. Comparison of multiple methods for quantification of microbial biofilms grown in microtiter plates. Journal of Microbiological Methods 72, 157-165.

Pompilio, A., Piccolomini, R., Picciani, C., D’Antonio, D., Savini, V., Di Bonaventura, G., 2008. Factors associated with adherence to and biofilm formation on poly- styrene by Stenotrophomonas maltophilia: the role of cell surface hydropho- bicity and motility. FEMS Microbiology Letters 287, 41-47. 
Saavedra, M.J., Borges, A., Dias, C., Aires, A., Bennett, R.N., Rosa, E.S., Simões, M., 2010. Antimicrobial activity of phenolics and glucosinolate hydrolysis products and their synergy with streptomycin against pathogenic bacteria. Medicinal Chemistry $6,174-183$.

Sarker, S.D., Nahar, L., Kumarasamy, Y., 2007. Microtitre plate-based antibacterial assay incorporating resazurin as an indicator of cell growth, and its application in the in vitro antibacterial screening of phytochemicals. Methods 42, 321-324.

Sarwar, M., Kirkegaard, J.A., Wong, P.T.W., Desmarchelier, J.M., 1998. Biofumigation potential of brassicas. Plant and Soil 201, 103e112.

Simões, L.C., Simões, M., Oliveira, R., Vieira, M.J., 2007. Potential of the adhesion of bacteria isolated from drinking water to materials. Journal of Basic Microbi- ology 47, 174183.

Simões, M., Rocha, R., Coimbra, M.A., Vieira, M., 2008. Enhancement of Escherichia coli and Staphylococcus aureus antibiotic susceptibility using sesquiterpenoids. Medicinal Chemistry 4, 616-623.

Simões, L.C., Simões, M., Vieira, M.J., 2010a. Adhesion and biofilm formation on polystyrene by drinking water-isolated bacteria. Antonie Van Leeuwenhoek 98, 317-329.

Simões, L.C., Simões, M., Vieira, M.J., 2010b. Influence of the diversity of bacterial isolates from drinking water on resistance of biofilms to disinfection. Applied and Environmental Microbiology 76, 6673-6679.

Simões, M., Simões, L.C., Vieira, M.J., 2010c. A review of current and emergent biofilm control strategies. LWT e Food Science and Technology 43, 573-583.

Smith, A.W., 2005. Biofilms and antibiotic therapy: is there a role for combating bacterial resistance by the use of novel drug delivery systems? Advanced Drug Delivery Reviews 57, 1539-1550.

Stepanovi c, S., Vukovi c, D., Daki c, I., Savic, B., Svabi Vlahovic, M., 2000. A modified microtiter-plate test for quantification of staphylococcal biofilm formation. Journal of Microbiological Methods 40, 175-179.

Stickland, H.G., Davenport, P.W., Lilley, K.S., Griffin, J.L., Welch, M., 2010. Mutation of nfxB causes global changes in the physiology and metabolism of Pseudomonas aeruginosa. Journal of Proteome Research 9, 2957-2967.

Talon, D., 1999. The role of the hospital environment in the epidemiology of multiresistant bacteria. Journal of Hospital Infection 43, 13-17.

van Loosdrecht, M.C., Lyklema, J., Norde, W., Schraa, G., Zehnder, A.J., 1987. Electrophoretic mobility and hydrophobicity as a measured to predict the initial steps of bacterial adhesion. Applied and Environmental Microbiology 53, 1898-1901.

Vapnek, J., Spreij, M., 2005. Perspectives and Guidelines on Food Legislation, with a New Model Food Law. 87. Food and Agriculture Organization (FAO), Rome.

Wutzler, P., Sauerbrei, A., Schau, H.P., 2005. Monopercitric acid e a new disinfectant with excellent activity towards clostridial spores. Journal of Hospital Infection 59, 75-76.

Xu, K.D., McFeters, G.A., Stewart, P.S., 2000. Biofilm resistance to antimicrobial agents. 
Microbiology 146, 547-549.

Zahin, M., Aqil, F., Khan, M.S.A., Ahmad, I., 2010. Ethnomedicinal plants derived antibacterials and their prospects. In: Chattopadhyay, D. (Ed.), Ethnomedicine: A Source of Complementary Therapeutics. Research Signpost, Kerala, pp. 149-178.

Zottola, E.A., Sasahara, K.C., 1994. Microbial biofilms in the food processing industry should they be a concern? International Journal of Food Microbiology 23, 125-148. 